\title{
Date and Their Processing Byproducts as Substrates for Bioactive Compounds Production
}

\author{
Zhen-Xing Tang ${ }^{1,3^{*}}$, Lu-E Shi ${ }^{2}$ and Salah Mohammed Aleid ${ }^{3}$ \\ ${ }^{1}$ Department of Food Science; Anqing Vocational \& Technical College; Anqing, Anhui - China. ${ }^{2}$ College of Life and \\ Environmental Sciences; Hangzhou Normal University; Hangzhou, Zhejiang - China. ${ }^{3}$ Date Palm Research Center; \\ King Faisal University; Al-hasa - Saudi Arabia
}

\begin{abstract}
Date is the most popular fruit in middle-east countries. However, the date production process is accompanied by a substantial increase of loss during picking, storage, commercialization and conditioning process. Date and their byproducts have many essential elements for the growth of microorganisms. Thus, they can be converted into valueadded compounds through biotechnology. In this paper, date and their processing byproducts used as substrates for producing value-added products such as organic acids, exopolysaccharide, antibiotics, date flavored probiotic fermented dairy, bakery yeast, etc, were reviewed.
\end{abstract}

Key words: Date, byproduct, biotechnology, fermentation, review

\section{INTRODUCTION}

As a high-value fruit, date is mainly produced in the South Asian and North African countries. The world production of date fruit is more than 7 million tons/year (FAO 2007). Carbohydrates are the major chemical constituents of date, mainly including glucose, fructose and small amounts of polysaccharides such as cellulose and starch (AlShahib and Marshall 2003; Al-Farsi et al. 2005). Date has high concentrations of protein (1-7\%), which contains essential amino acids needed by human body (Al-Showiman 1998). Date has large amounts of dietary fiber. It also is thought to be a good source of some minerals such as iron, potassium and calcium et al. However, the date production process involves substantial loss of dates that occur during the picking, storage, marketing and conditioning process. Lost dates, termed as "by-products", which account for more than 2,000,000 tones every year, are discarded due to their inadequate texture (Besbes et al. 2005, 2006). Hence, it would be useful to develop the efficient and cost-effective method to utilize these dates for the production of value-added products through fermentation. This paper reviews the prospects of using date and their by-products as substrates for producing value-added products such as organic acids, exopolysaccharide, antibiotics, date flavored probiotic dairy, bakery yeast, etc.

\section{DATE AND THEIR BY-PRODUCTS AS SUBSTRATES FOR THE PRODUCTION OF BIO-ACTIVE SUBSTANCES \\ Because date and their by-products have nutritive components for microbial growth, fermentation products using date and their by-products as substrates have been reported. Table 1 shows some important fermentation products prepared using date and their by-products as substrates.}

*Author for correspondence: tangzhenxing@126.com 
Table 1 - Fermentation products from date and their by-products.

\begin{tabular}{|c|c|c|}
\hline Fermentation products & Strains & References \\
\hline Citric acid & A. niger & $\begin{array}{l}\text { Mehyar et al. (2005), Mostafa and } \\
\text { Alamri (2012) }\end{array}$ \\
\hline \multirow[t]{2}{*}{ Lactic acid } & Lactobacillus sp. KCP01 & Chauhan et al. (2007) \\
\hline & Lactobacillus casei subsp. Rhamnosus & Nancib et al. (2005) \\
\hline $\mathrm{BC}$ & Gluconacetobacter xylinus & Moosavi-Nasab and Yousefi (2011) \\
\hline Curdlan & Rhizobium radiobacter ATCC 6466 & Salah et al. (2011) \\
\hline Xanthan gum & Xanthomonas campestris & $\begin{array}{l}\text { Moosavi-Nasab et al. (2009), Salah } \\
\text { et al. (2010), Salah et al. (2011) }\end{array}$ \\
\hline BLM & Streptomyces mobaraensis & Radwan et al. (2010) \\
\hline \multirow[t]{3}{*}{ Fermented dairy product } & Bifidobacterium lactis $\mathrm{Bb}-12$, B. longum $\mathrm{Bb}-$ & Al-Otaibi and Saleh (2010) \\
\hline & 46 and Lactobacillus acidophilus La-5 & Khan et al. (1995), Nancib et al. \\
\hline & S. cerevisiae & (1997), Al-Jasass et al. (2010) \\
\hline Yeast & L. plantarum QS3 & Elsanhoty et al. (2012) \\
\hline Carotenoids & Corynebacterium glutamicum CЕСТ690 & \multirow{3}{*}{$\begin{array}{l}\text { Tavakkoli et al. (2012), Davati et al. } \\
\text { (2007) }\end{array}$} \\
\hline GA & Bacillus spp & \\
\hline PHAs & Clostridium acetobutylicum ATCC 824 and & \\
\hline $\mathrm{ABE}$ & $\begin{array}{l}\text { Bacillus subtilis DSM } 4451 \\
\text { Saccharomyces cerevisiae var. ellipsoideus }\end{array}$ & Khiyami et al. (2011) \\
\hline & Candida utilis and Saccharomyces cerevisiae & Abd-Alla and Ei-Enany (2012) \\
\hline Wine & LAB & Shi et al. (2005) \\
\hline SCP & & Aleid et al. (2010) \\
\hline Nisin & & Khiyami et al. (2008) \\
\hline
\end{tabular}

\section{ORGANIC ACID}

\section{Citric acid}

Citric acid has been widely used in food, pharmaceutical and chemical industries due to its low toxicity (Drysdale and Mckay 1995; Radwan et al. 2010). In 2008, the citric acid production was over 1.6 million tons and this trend was expected to increase (Husseiny et al. 2010). Because of its wide use, high quality of volumes and low production cost of citric acid are of great interest to the industries. In order to decrease the cost of the production, interest in using agro-industrial residues and by-products has increased. Mehyar et al. (2005) studied the ability of Aspergillus niger to produce citric acid from dates. Two strains of $A$. niger were grown in the media containing different concentrations of date extract fortified with whey, methanol and tricalcium phosphate. The results showed that the addition of whey, methanol and tricalcium phosphate to the date medium improved the production of citric acid. The concentrations of citric acid reached to 38.4 and $42.4 \mathrm{~g} / \mathrm{L}$, respectively in date medium fortified with methanol and tricalcium phosphate. Acourene et al. (2011) investigated the potential of date wastes as substrates for the production of citric acid using
Saccharomyces cerevisiae ATCC 1102 and A. niger ATCC 16404.

The results showed that the optimal fermentation conditions were fermentation time $144 \mathrm{~h}, \mathrm{pH}$ and temperature 3.5 and $30^{\circ} \mathrm{C}$, respectively using a medium containing $(\mathrm{g} / \mathrm{L})$ sugar 150 , ammonium nitrate 2.5 and potassium phosphate 2.5. Under optimal conditions, $126.4 \mathrm{~g} / \mathrm{L}$ citric acid was produced. Mostafa and Alamri (2012) used immobilized $A$. niger cells to produce citric acid. One of the most important advantages of immobilized cells is their ability and stability to produce citric acid under a repeated batch culture. Over four repeated batches, the production of citric acid production was maintained for 24 days. The results also showed that the appropriate presence of nitrogen, phosphate and magnesium appeared to be important for the production of citric acid. All above obtained results confirmed that date and their by-products could be used as substrates for the production of citric acid.

\section{Lactic acid}

Lactic acid is a valuable industrial chemical that is used as a preservative in food and beverage industries. Lactic acid can be obtained through fermentation. While most of the studies on lactic 
acid fermentation are focused on using refined carbohydrates such as glucose (Ishida et al. 2006; Yadav et al. 2009), or starch hydrolysate (Tanaka et al. 2006), it has been found that the cost of the medium alone accounts for $60-80 \%$ of the total production cost, thus making it imperative to use economical agricultural residues and by-products. Chauhan et al. (2007) screened media components for the production of lactic acid by Lactobacillus sp. KCP01 and obtained $2.6 \mathrm{~g} / \mathrm{L}$ of lactic acid using date juice alone at 5\% sugar concentration. The increase of the concentration of lactic acid $(15.1 \mathrm{~g} / \mathrm{L})$ was observed when salts and organic nitrogen sources were supplemented into the medium. Nancib et al. (2005) investigated the production of lactic acid by $L$. casei subsp. The addition of five $B$ vitamins at less than $25 \mathrm{mg} / \mathrm{L}$ to date juice could enhance the production of lactic acid. Yadav et al. (2011) produced lactic acid using L. delbruckii, under optimal production medium comprising (\%) 10 date syrup, 1 yeast extract, 0.6 sodium acetate, $0.5 \mathrm{KH}_{2} \mathrm{PO}_{4}$, and 0.5 $\mathrm{MgSO}_{4} \cdot 7 \mathrm{H}_{2} \mathrm{O}$. High lactic acid productivity was obtained.

\section{Acetic acid}

Acetic acid is an important chemical product and has been widely used in food and pharmaceutical industries. Due to depleting natural resources, the production of acetic acid by microbial fermentation has attracted much interest. The production of acetic acid from dates mainly involves two stages. In the first stage, sugar in date juice is converted into alcohol by Saccharomyces sp. In the second stage, alcohol is converted into acetic acid by Acetobacter sp. The commonly used organisms for the production of acetic acid are $S$. cerevisiae, S. ellipsoideus, Acetobacter xylinum, and A. cycendens (Sokollek et al. 1998; Manickavasagan 2012).

\section{EXO-POLYSACCHARIDES Bacterial Cellulose (BC)}

$\mathrm{BC}$ is an exo-polysaccharide produced by various species of bacteria (Chawla et al. 2009), having good properties such as free of undesirable components (lignin and hemicelluloses), high polymer crystallinity and high degree of polymerization. Due to its unique properties and structure, BC has many applications in a variety of food formulations (Khan et al. 2007). MoosaviNasab and Yousefi (2011) utilized low quality date syrup for the production of BC using Gluconacetobacter xylinus and obtained $4.35 \mathrm{~g} \mathrm{BC}$ $/ 100 \mathrm{~mL}$ of date syrup after $336 \mathrm{~h}$ fermentation. SEM results revealed more delicacy in the structure of bacterial cellulose. X-ray diffractometry demonstrated that the crystallinity level of standard cellulose $(83.61 \%)$ was higher than that of bacterial cellulose $(60.73 \%)$. This showed that date syrup could be used as a substrate for the production of BC.

\section{Curdlan}

Curdlan is a neutral, water-insoluble and linear polysaccharide, which is primarily composed of $\beta$ - (1-3)-linked glucose (Delattre et al. 2009; West 2009). Curdlan has been reported as a useful additive for a variety of food products, such as noodles, sauces, frozen foods and packaged meats (Arocas; Sanz and Fiszman 2009; Zhang and Nishinari 2009). The currently available commercialized curdlan is relatively expensive. This is mainly because of using expensive carbon sources, namely glucose and sucrose. So, in order to increase its economic attractiveness, its production cost should be decreased (Funami and Nishinari 2007; Zhang and Nishinari 2009). Salah et al. (2011) investigated the possibility of using date by-products for curdlan production by Rhizobium radiobacter ATCC 6466. The strain exhibited a good ability to use the substrate yielding $22.83 \mathrm{~g}$ curdlan/L under optimal conditions in a medium containing $(\mathrm{g} / \mathrm{L})$ ammonium sulphate 2, date glucose juice concentration $120, \mathrm{pH} 7.0$ temperature $30^{\circ} \mathrm{C}$, agitation speed $180 \mathrm{r} / \mathrm{min}$ and fermentation time $51 \mathrm{~h}$. The purified curdlan had a molecular weight of $180 \mathrm{kDa}$. Melting temperature $\left(\mathrm{T}_{\mathrm{m}}\right)$ and glass transition temperature $\left(\mathrm{T}_{\mathrm{g}}\right)$ were 1.24 and $-3.55^{\circ} \mathrm{C}$, respectively.

\section{Xanthan Gum}

Xanthan gum is the most commercially produced industrial gum (Kalogiannis et al. 2003). It has been widely used as a thickening, or stabilizing agent in food, pharmaceutical and oil-recovery industries. The main chain of xanthan consists of glucose molecules connected by $\beta-1,4$ glycosidic links. Every second glucose unit carries a side chain that is composed of $\beta$-D-mannose, $\beta-1$, 4-D-

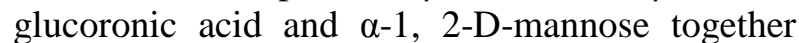
with a pyruvic acid unit (Rosalam and England 2006). Moosavi-Nasab et al. (2009) used Xanthomonas campestris for producing xanthan 
gum employing date syrup as a substrate. The results showed that gum concentration increased with an increase in fermentation time with a maximum yield of $0.89 \mathrm{~g} / 100 \mathrm{~mL}$ after $96 \mathrm{~h}$. The xanthan obtained showed a very similar chemical composition compared to commercial xanthan. Salah et al. (2010, 2012) investigated and optimized xanthan gum production by $X$. campestris NRRL B-1459. The results showed that this strain had a high ability to metabolize date byproducts. The optimal conditions were $84.68 \mathrm{~g} / \mathrm{L}$ carbon source, $2.7 \mathrm{~g} / \mathrm{L}$ nitrogen source, and $30.1^{\circ} \mathrm{C}$ temperature, which produced $43.35 \mathrm{~g} / \mathrm{L}$ curdlan. This was close to the $42.96 \mathrm{~g} / \mathrm{L}$ value predicted by the Response Surface Methodology (RSM) model.

\section{Antibiotics}

Oxytetracycline is a broad-spectrum antibiotic produced by different species of Streptomyces. The antibiotic is active on Gram-positive and Gram-negative bacteria. Abou-Zeid et al. (1993) utilized date constituents as a nutrient medium for the production of oxytetracycline. Their results showed that the addition of $1.0 \mathrm{~g} / \mathrm{L}$ urea and dateseed lipid into the medium increased the efficacy for antibiotic formation. When $\mathrm{MgSO}_{4}, \mathrm{MnSO}_{4}$, $\mathrm{FeSO}_{4}$ and $\mathrm{ZnSO}_{4}$ components of the medium were replaced by $0.5 \mathrm{~g} / \mathrm{L}$ date-seed ash, antibiotic output was also increased.

Bleomycin (BLM) is a family of glycopeptidederived antibiotics (Troost et al. 2009). BLM has a strong antitumor activity and therefore, it has been widely employed for the treatment of several malignancies, including non-Hodgkin's lymphoma, squamous cell carcinoma and testicular tumors (Aras and Dilsizian 2008; Evens et al. 2008). Radwan et al. (2010) optimized the composition and concentration of a liquid fermentation medium for the production of BLM by $S$. mobaraensis. When date syrup was used as an additional carbon source, higher BLM amount was obtained compared to glucose. Under the optimal conditions, BLM yield was $138 \mathrm{mg} / \mathrm{L}$. The complex medium containing $40 \mathrm{~g} / \mathrm{L}$ date syrup as additional carbon source enhanced the production of BLM by $73 \%$.

\section{Date probiotic fermented products}

Fermented dairy products are beneficial for the health (Parodi 1999). Hashim (2001) studied the characteristics and acceptability of yogurt containing dates. The results indicated that addition of $10-20 \%$ of date paste with, or without
5\% date syrup did not affect yogurt acidity, protein, or fat contents, but increased total solids significantly. Also, the addition of $15 \%$ date paste with 5\% date syrup provided yogurt with desired sensory quality. Gad et al. (2010) used dates in reconstituting skimmed milk powder in processing yogurt with $14 \%$ total solids. The results showed that yogurt enriched with $10 \%$ dates had a significant sweetness, higher antioxidant values, higher in $\mathrm{HCl}$ soluble minerals and folate concentration compared to plain yogurt. The addition of date syrup to the probiotic yogurt enhanced the bifidobacterial count of the products and improved their survival during the cool storage period up to 10 days. This could be explained on the basis that date syrup contained some micronutrients, such as vitamins and minerals, which would enhance the growth of bifidobacteria. Al-Otaibi and Saleh (2010) incorporated probiotic microorganisms Bifidobacterium lactis Bb-12, B. longum Bb-46 and $L$. acidophilus La-5 into date pastes. All probiotic bacteria were capable of surviving in dates. The viable count of $L$. acidophilus remained above $6 \log _{10} \mathrm{CFU} / \mathrm{g}$ until the third week of storage. The viable count of $B$. lactis and $B$. longum remained above $6 \log _{10} \mathrm{CFU} / \mathrm{g}$ until the eighth and tenth weeks of storage.

In order to get the information on the sugar utilization in fermenting milk, Hartati et al. (2012) added date into yogurt drink with different percentage. The result showed that adding date from 3.19 to $3.32 \%$, reducing sugar increased persistently from 2.15 to $2.99 \%$, and $\mathrm{pH}$ value decreased from 3.8 to 3.76. However, adding date into yogurt drink had no effect on sourness. This study indicated that lactose and reduced sugar concentration and $\mathrm{pH}$ value of fermented milk could be affected due to utilization of date by the lactic acid bacteria (LAB).

\section{Yeast}

Dates are a good potential substrate for the production of bakery yeast. Khan et al. (1995) used Saudi Arabian dates for the production of baking yeast. They propagated six different strains of $S$. cerevisiae in fermentation medium containing date extract (with $60 \%$ sugars), in addition to $2 \mathrm{~g} / \mathrm{L}$ ammonium sulfate and $50 \mathrm{mg} / \mathrm{L}$ biotin. Yields about $42.8 \%$ of the theoretical were obtained. Nancib et al. (1997) used date byproducts for the production of baking yeast from $S$. cerevisiae. Although this medium was satisfactory 
for the production of the yeast, yields obtained were very low with a maximum of $0.60 \mathrm{~g} / \mathrm{L}$ biomass concentration in the fermentation medium compared to the optimum of about $40 \mathrm{~g} / \mathrm{L}$ expected for an economical production. AlJasass et al. (2010) used date syrup and molasses for the propagation of baking yeast strain $S$. cerevisiae. The results showed that the overall biomass yield from date syrup substrate was significantly lower than the yields from molasses. Reduced yields could be attributed to the effect of toxic organic acids contained in date syrup at high concentrations. Ei-Sharnouby et al. (2010) investigated the performance of the produced baker's yeasts on Arabic bread quality. Their results indicated that the yeast produced from date syrup was comparable to the yeast produced from molasses. There were insignificant differences in gassing power between the yeasts produced from date syrup and molasses. Thus, it was concluded that excellent quality baker's yeast could be produced using date syrup as a substrate.

\section{OTHER VALUE-ADDED PRODUCTS Carotenoid}

Carotenoids are natural pigments responsible for the pleasing colors of many foods. Some carotenoids are the precursors of vitamin $\mathrm{A}$, which have beneficial effects on human health, including enhancement of the immune system and reduction of the risk for degenerative diseases such as cancer, cardiovascular diseases and cataract (Krinsky 2001; Garrido-Fernández et al. 2010). The commercial utilization of microorganisms to produce carotenoids is presently limited by the high cost of production. However, the cost of carotenoids production by fermentation could be minimized by using cheap industrial by-products (Aksu and Tugba 2005). Elsanhoty et al. (2012) used date wastes for the production of carotenoids. L. plantarum QS3 gave the highest production. Date syrup at $5 \%$ sugar concentration produced $16.21 \mathrm{mg} / \mathrm{kg}$ dry cell of carotenoids when used alone. Plackett-Burman design showed peptone, $\mathrm{K}_{2} \mathrm{HPO}_{4}$, sodium acetate and date juice affected the production of carotenoids. Carotenoids yield $(54.89 \mathrm{mg} / \mathrm{kg}$ dry cell) was observed under optimized conditions.

\section{Amino acid}

Glutamate (GA) is mainly used as a flavoring agent (Nandakumar et al. 2003, Jyothi et al. 2005).
According to Shimizu and Hirasawa (2006), the production of GA was more than 1.5 million tons per year worldwide (Shimizu and Hirasawa 2006). Efforts have been made to improve the GA fermentation process, especially from the standpoint of saving the production cost. Tavakkoli et al. (2012) used RSM to evaluate the effect of fermentation parameters for the production of GA using date waste as a substrate. The optimized fermentation conditions were inoculum size $2 \%(\mathrm{v} / \mathrm{v})$, substrate concentration $25 \%(\mathrm{w} / \mathrm{v})$, penicillin concentration $1 \mathrm{U} / \mathrm{mL}$, phosphate concentration $4 \mathrm{~g} / \mathrm{L}$, and inoculum age $10 \mathrm{~h}$, the resulting maximum GA $(39.32 \mathrm{mg} / \mathrm{mL})$. Davati et al. (2007) used two mutants $C$. glutamicum CECT690 and CECT77 to study the possibility of producing amino acids from date wastes. According to the results, the most effective factors on the production of GA were the amount of date fruit wastes, time of penicillin addition, phosphate amount and type of microorganism. The results demonstrated date waste juice as a substrate has the potential for producing GA.

\section{Polyhydroxyalkanoates (PHAs)}

PHAs are a group of renewable and biodegradable biopolymers that have thermoplastic properties. The production cost of biopolymers is a crucial parameter compared with that of chemical synthetic non-biodegradable plastics (Bengtsson et al. 2010). Hitherto, the low cost raw materials, such as date syrup, industrial waste and municipal waste et al., could be significant parameter for reducing the production cost. Khiyami et al. (2011) tested the accumulation ability of PHAs in Bacillus spp using date syrup as substrate and obtained $8.3 \mathrm{~g} / \mathrm{L}$ cellular dry matter with almost $70.5 \%$ PHA content. The average molecular weight range was between 3.7 to $4.1 \times 10^{5} \mathrm{~g} / \mathrm{mol}$. This study demonstrated that date syrup could be evaluated as a complex media supplement to meet the nutritional requirements for the production of PHA.

\section{Biofuel}

The most commonly used metabolically derived liquid biofuels are acetone, butanol and ethanol (ABE). ABE are commonly used solvents in many important industries and have a high potential for replacing the petrochemical derived energy. Substrate costs can make up to about $63 \%$ of the total cost of ABE production (Kumar et al. 2011). Hence, substrates such as agricultural residues 
offer potential alternatives (Qureshi et al. 2010 a, b, c). Abd-Alla and EI Enany (2012) studied spoilage date palm (Phoenix dactylifera L.) fruit as substrate for $\mathrm{ABE}$ production by mixed culture of C. acetobutylicum ATCC 824 and B. subtilis DSM 4451 and achieved $21.56 \mathrm{~g} / \mathrm{L} \mathrm{ABE}$ from $75 \mathrm{~g} / \mathrm{L}$ spoilage date fruit homogenate. The addition of yeast extract $(5 \mathrm{~g} / \mathrm{L})$, or ammonium nitrate $(1.6$ $\mathrm{g} / \mathrm{L})$ significantly enhanced $\mathrm{ABE}$ production. These results suggested that spoilage date fruit could be efficiently used for commercial ABE production.

\section{Wine}

Wine is a drink derived from the fruits and sometimes vegetables. Being rich in fermentable sugars, date juice could be a good raw material for wine making. A suitable strain for preparing a good quality date wine (12\% ethanol, $0.35-0.54 \%$ acidity, and $\mathrm{pH}$ of 4.0-4.2) is $S$. cerevisiae var. ellipsoideus (Shi et al. 2005). In the production of wine, alcohol is one of the constituents of the endproducts and some by-products such as $\mathrm{CO}_{2}$ are also produced.

\section{Single Cell Protein (SCP)}

$\mathrm{SCP}$, a protein source, is used to replace protein concentrates in animal feeds. SCP can be produced from bacteria, yeasts, molds and algae using different substrates as sources of carbon. Aleid et al. (2010) described Candida utilis and S. cerevisiae for the production of SCP using date syrup as a substrate. Biomass yields could reach more than $90 \%$ of the theoretical, and the protein content of the biomass was about $50 \%$. The amino acid composition of the proteins was high-quality containing most of the essential amino acids, especially lysine and the sulfur containing amino acids.

\section{Nisin}

Nisin is the most common kind of bacteriocins, produced by certain types of LAB. Khiyami et al. (2008) studied the potential of using a variety of dates and their byproducts date pits as complex medium for the production of nisin. Low concentration of date syrup $5.0 \%$ enhanced the yield of nisin. The production of nisin began after $2 \mathrm{~h}$ of incubation and reached maximum after $12 \mathrm{~h}$ of incubation. The optimal concentration of dates pits and dates syrup for LAB growth and nisin production was 1.5 and $5.0 \%$, respectively.

\section{CONCLUSIONS}

Many reports have indicated that date and its processing by-products are good substrates for the production of fermentation products. Utilizing dates and their by-products in industrial biotechnology could offer economic, social and environmental benefits. Efforts should be made to explore new and improved microorganisms that can convert date into end-products and new bioactive compounds.

\section{REFERENCES}

Abd-Alla MH, Ei-Enany AE. Production of acetonebutanol-ethanol from spoilage date palm (Phoenix dactylifera L.) fruits by mixed culture of Clostridium acetobutylicum and Bacillus subtilis. Biomass Bioenergy. 2012; 42: 172-178.

Abou-Zeid AA, Baeshin NA, Baghlaf AO. Utilization of date products in production of oxytetracycline by streptomyces rimosus. J Chem Technol Biotechnol. 1993; 58: 77-79.

Acourene S, Djafri K, Ammouche A, Djidda A, Tama M, Taleb B. Utilisation of the date wastes as substrate for the production of baker's yeast and citric acid. Biotechnol. 2011; 10: 488-497.

Aksu Z, Tugba AT. Carotenoid production by the yeast Rhodotorula mucilaginosa: use of agricultural wastes as a carbon source. Process Biochem. 2005; 40: 29852991.

Aleid SM, Al-jasass FM, Hamad SH. Second annual report of Project \# APR-27-96, Production of single cell protein from surplus dates and its use as a protein source in the diets of poultry and fish. King Abdulaziz City for Science and Technology, Riyadh, 2010.

Al-Farsi M, Alaslvar C, Morris A, Baron M, Shahidi F. Comparison of antioxidant activity, anthocyanins, carotenoids and phenolics of three native flesh and sundried date (Phoenix dactylifera L.) varieties grown in Oman. J Agric Food Chem. 2005; 53: 7592-7599.

Al-Jasass FM, Aleid SM, Ali SHH. A comparative study on date syrup (dips) as substrate for the production of baker's yeast (Saccharomyces cerevisiae). J Food Agric Environ. 2010; 8: 314-316.

Al-Otaibi MM, Saleh FA. Annual report of Project No.110003, Fortification of some dates with probiotic fermented milk, King Faisal University, AlHassa, 2010.

Al-Shahib W, Marshall RJ. The fruit of the date palm: its possible use as the best food for the future. Int J Food Sci Nutr. 2003; 54: 247-259.

Al-Showiman SS. Date, food and health. Qassim, Saudi Arabia: Dar Al-Khareji Press; 1998.

Aras O, Dilsizian V. Targeting tissue angiotensinconverting enzyme for imaging cardiopulmonary fibrosis. Curr Cardiol Rep. 2008; 10: 128-134. 
Arocas A, Sanz T, Fiszman SM. Improving effect of xanthan and locust bean gums on the freeze-thaw stability of white sauces made with different native starches. Food Hydrocolloids. 2009; 23: 2478-2484.

Barnett JA, Payne RW, Yarrow D. Yeasts: characteristics and identification, 3rd end. Cambridge: Cambridge University Press; 2000.

Bengtsson S, Pisco A R, Reis MAM, Lemos PC. Production of polyhydroxyalkanoates from fermented sugar cane molasses by a mixed culture enriched in glycogen accumulating organisms. J Biotechnol. 2010; 145: 253-263.

Besbes S, Cheikh Rouhou S, Blecker C, Derouanne C, Lognay G, Drira NE. Voies de valorisation des sous produits de dattes: Valorisation de la pulpe. Microbiologie Hygiène Alimentaire. 2006; 18: 3-7.

Besbes S, Hentati B, Blecker C, Derouanne C, Lognay G, Drira NE. Voies de valorisation des sous produits de dattes: Valorisation du noyau. Microbiologie Hygiène Alimentaire. 2005; 18: 3-11.

Chauhan K, Trivedi U, Patel KC. Statistical screening of medium components by Plackett-Burman design for lactic acid production by Lactobacillus sp. KCP01 using date juice. Bioresource Technol. 2007; 98: 98-103.

Chawla PR, Bajaj IB, Shrikant AS, Singhal RS. Fermentative production of microbial cellulose. Food Technol Biotechnol. 2009; 47:107-124.

Davati N, Hamidi EZ, Shoja ASA. Study on producing possibility of amino acids from date palm wastes by two mutant corynebacterium glutamicum CECT 690 and CECT77. Iran J Food Sci Tech. 2007; 4: 55-64.

Delattre C, Rios L, Laroche C, Le NH, Lecerf D, Picton L, et al. Production and characterization of new families of polyglucuronic acids from TEMPO- $\mathrm{NaOCl}$ oxidation of curdlan. Int J Biol Macromolc. 2009; 45: 458-462.

Drysdale CR, McKay AM. Citric acid production by Aspergillus niger in surface culture on inulin. Lett Appl Microbiol. 1995; 20: 252-254.

Elsanhoty RM, Al-Turki IA, Ramadan MF. Screening of medium components by Plackett-Burman design for carotenoid production using date (Phoenix dactylifera) wastes. Ind Crop Prod. 2012; 36: 313-320.

EI-Sharnouby G A, Aleid SM, Al-otaibi MM. Utilization of enzymes in the production of liquid sugar from dates, Afr J Biochem Res. 2010; 3: 41-47.

Evens AM, Hutchings M, Diehl V. Treatment of Hodgkin lymphoma: the past, present, and future. Nat Clin Pract Oncol. 2008; 5: 543-556.

FAO (2007). updated June 2, 2012. Available from Statistical Databases; http://faostat.fao.org.

Funami T, Nishinari K. Gelling characteristics of curdlan aqueous dispersions in the presence of salts. Food Hydrocolloids. 2007; 21: 59-65.

Gad AS, Kholif AM, Sayed AF. Evaluation of the nutritional value of functional yogurt resulting from combination of date palm syrup and skim milk. Am J Food Technol. 2010; 5: 250-259.

Garrido-Fernández J, Maldonado-Barragán A, CaballeroGuerrero B, Hornero-Méndez D, Ruiz-Barba JL. Carotenoid production in Lactobacillus plantarum. Int $J$ Food Microbiol. 2010; 140: 34-39.
Hartati AI, Pramono YB, Legowo AM. Lactose and reduction sugar concentrations, $\mathrm{pH}$ and the sourness of date flavored yogurt drink as probiotic beverage. J Appl Food Technol. 2012; 1: 1-3.

Hashim IB. Characteristics and acceptance of yoghurt containing date palm products. In: Second international conference on date palms; 2001, 25-26 Mar, Al-Ain, United Arab Emirates, p 842-849.

Husseiny SM, Helemish FA, Younis NA, Farag SS. Selection of most potent $A$. niger isolates growing on different carbohydrate by-products for citric acid production. J Am Sci. 2010; 6: 1222-1229.

Ishida N, Saitoh S, Ohnishi T, Tokuhiro K, Nagamori E, Kitamoto $\mathrm{K}$, et al. Metabolic engineering of Saccharomyces cerevisiae for efficient production of pure L-(+)-lactic acid. Appl Biochem Biotechnol. 2006; 131: 795-807.

Jyothi AN, Sasikiran K, Nambisan B, Balagopalan C. Optimisation of glutamic acid production from cassava starch factory residues using Brevibacterium divaricatum. Process Biochem. 2005; 40: 3576-3579.

Kalogiannis S, Iakovidou G, Liakopoulou-Kyriakides M, Kyriakidis DA, Skaracis GN. Optimization of xanthan gum production by Xantomonas campestris grown in molasses. Process Biochem. 2003; 39: 249-256.

Khan JA, Abulnaja KO, Kumosani TA, Abou-Zaid AA. Utilization of Saudi date sugars in production of baker's yeast. Bioresource Technol.1995; 53: 63-66.

Khan T, Park JK, Kwon JH. Functional biopolymers produced by biochemical technology considering applications in food engineering. Korean J Chem Eng. 2007; 24: 816-826.

Khiyami M, Aboseide B, Pometto A. Influence of complex nutrient sources: dates syrup and dates pits on Lactococcus lactis growth and nisin production, $J$ Biotechnol. 2008; S736.

Khiyami MA, Al-Fadual SM, Bahklia AH. Polyhydroxyalkanoates production via Bacillus plastic composite support (PCS) biofilm and date palm syrup. $J$ Med Plants Res. 2011; 5: 3312-3320.

Krinsky NI. Carotenoid antioxidants. Nutr. 2001; 17: 815817.

Kumar M, Gayen K. Developments in biobutanol production: New insights. Appl Energy. 2011; 88: 19992012.

Manickavasagan, A, Mohamed Esa, M, Sukumar, E. Dates: production, processing, food and medicinal values. New York: CRC Process; 2012.

Mehyar GF, Delaimy KS, Ibrahim SA. Citric acid production by Aspergillus niger using date-based medium fortified with whey and additives. Food Biotechnol. 2005; 19: 137-144.

Moosavi-Nasab M, Shekaripour F, Alipoor M. Use of date syrup as agricultural waste for xanthan production by Xanthomonas campestris. Iran Agric Res. 2009; 28: 8997.

Moosavi-Nasab M, Yousefi A. Biotechnological production of cellulose by Gluconacetobacterxylinus from agricultural waste, Iran J Biotechnol. 2011; 9: 94101. 
Mostafa YS, Alamri SA. Optimization of date syrup for enhancement of the production of citric acid using immobilized cells of Aspergillus niger. Saudi J Biol Sci. 2012; 19: 241-246.

Nancib N, Nancib A, Boudrant J. Use of waste date products in the formation of baker's yeast biomass by Saccharomyces cerevisiae. Bioresource Technol. 1997; 60: 67-71.

Nancib A, Nancib N, Meziane-Cherif D, Boubendir A, Fick M, Boudrant J. Joint effect of nitrogen sources and B vitamin supplementation of date juice on lactic acid production by Lactobacillus casei subsp. Rhamnosus, Bioresource Technol. 2005; 96: 63-67.

Nandakumar R, Yoshimune K, Wakayama M, Moriguchi M. Review: microbial glutaminase: biochemistry, molecular approaches and applications in the food industry. J Mol Catal B: Enzymatic. 2003; 23: 87-100.

Parodi PW. The role of intestinal bacteria in the causation and prevention of cancer: modulation by diet and probiotics. Aust J Dairy Tech. 1999; 54: 103-121.

Qureshi N, Saha BC, Hector RE, Dien B, Hughes SR, Liu $\mathrm{S}$, et al. Production of butanol (a biofuel) from agricultural residues: part II e use of corn stover and switchgrass hydrolysates. Biomass Bioenergy. 2010a; 34: 566-571.

Qureshi N, Saha BC, Dien B, Hector RE, Cotta MA. Production of butanol (a biofuel) from agricultural residues: part I- use of barley straw hydrolysate. Biomass Bioenergy. 2010b; 34: 559-565.

Qureshi N. Agricultural residues and energy crops as potentially economical and novel substrates for microbial production of butanol (a biofuel). $C A B$ Reviews. 2010c; 5: 1-8.

Radwan H, Alanazi FK, Taha EI, Dardir HA, Moussa IM. Development of a new medium containing date syrup for production of bleomycin by Streptomyces mobaraensis ATCC 15003 using response surface methodology. Afr J Biotechnol. 2010; 9: 5450-5459.

Rosalam S, England R. Review of xanthan gum production from unmodified starches by Xanthomonas camprestris sp. Enzyme Microb Tech. 2006; 39: 197-207.

Salah RB, Chaari K, Besbes S, Ktari N, Blecker C, Deroanne $\mathrm{C}$, et al. Optimization of xanthan gum production by palm date (Phoenix dactyliferal L.) juice by-products using response surface methodology. Food Chem. 2010; 12: 627-633.

Salah RB, Chaari K, Besbes S, Ktari N, Blecker C, Deroanne $\mathrm{C}$, et al. Production of xanthan gum from Xanthomanas Campestris NRRL B-1459 by fermentation of date juice palm by-products (Phoenix dactyliferal L.). J Food Process Eng. 2011; 34: 457-474.
Salah RB, Jaouadi B, Bouaziz A, Chaari K, Blecker C, Derrouane $C$, et al. Fermentation of date palm juice by curdlan gum production from Rhizobium radiobacter ATCC $6466^{\mathrm{TM}}$ : purification, rheological and physicchemical characterization. LWT-Food Sci Technol. 2011; 44: 1026-1034.

Shi J, Ho C, Shahidi F. Asian functional foods. New York: CRC Press; 2005.

Shimizu H, Hirasawa T. Production of glutamate and glutamate-related amino acids: molecular mechanism analysis and metabolic engineering. Microb Monogr. 2006; 5: 1-38.

Sokollek, SJ, Hertel, C, Hammes, WP. Cultivation and preservation of vinegar bacteria. J Biotechnol. 1998; 60:195-206.

Tanaka T, Hoshima M, Tanabe S, Sakai K, Ohtsubo S, Taniquchi M. Production of D-lactic acid from defatted rice bran by simultaneous saccharification and fermentation. Bioresource Technol. 2006; 97: 211-217.

Tavakkoli M, Hamidi-Esfahani Z, Azizi MH. Optimization of Corynebacterium glutamicum glutamic acid production by response surface methodology. Food Bioprocess Tech. 2012; 5: 92-99.

Troost MM, Sternberg CN, De Wit R. Management of good risk germ-cell tumours. British J Urol Int. 2009; 104: 1387-1391.

West TP. Elevated curdlan production by a mutant of Agrobacterium sp. ATCC 31749. J Basic Microbiol. 2009; 49: 589-592.

Yadav AK, Bipinraj NK, Chaudhari AB, Kothari RM. Production of $\mathrm{L}(+)$ lactic acid from sweet sorghum, date palm, and golden syrup as alternative carbon sources, Starch. 2011; 63: 632-636.

Yadav AK, Chaudhari AB, Kothari RM. Enhanced viability of Bacillus coagulans after spray drying with calcium lactate, storage and re-hydration. Indian J Chem Tech. 2009; 16: 519-522.

Zhang H, Nishinari K. Characterization of the conformation and comparison of shear and extensional properties of curdlan in DMSO. Food Hydrocolloids. 2009; 23: 1570-1571.
Received: May 15, 2013; Accepted: August 12, 2013. 